\title{
Article \\ Effects of High-Impact Weight-Bearing Exercise on Bone Mineral Density and Bone Metabolism in Middle-Aged Premenopausal Women: A Randomized Controlled Trial
}

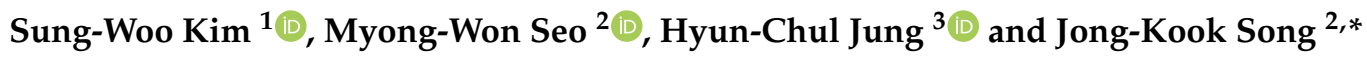 \\ 1 Department of Physical Education, Graduate School, Kyung Hee University (Global Campus), \\ 1732 Deokyoungdaero, Giheung-gu, Yongin-si 17014, Gyeonggi-do, Korea; kswrha@khu.ac.kr \\ 2 Department of Sports Science \& Medicine, Graduate School of Physical Education, \\ Kyung Hee University (Global Campus), 1732 Deokyoungdaero, \\ Giheung-gu, Yongin-si 17014, Gyeonggi-do, Korea; myongwonseo@khu.ac.kr \\ 3 Department of Coaching, College of Physical Education, Kyung Hee University (Global Campus), \\ 1732 Deokyoungdaero, Giheung-gu, Yongin-si 17014, Gyeonggi-do, Korea; jhc@khu.ac.kr \\ * Correspondence: jksong@khu.ac.kr; Tel.: +82-31-201-2700
}

check for updates

Citation: Kim, S.-W.; Seo, M.-W.; Jung, H.-C.; Song, J.-K. Effects of High-Impact Weight-Bearing Exercise on Bone Mineral Density and Bone Metabolism in Middle-Aged Premenopausal Women: A Randomized Controlled Trial. Appl. Sci. 2021, 11, 846. https://doi.org/ 10.3390/app11020846

Received: 16 November 2020

Accepted: 16 January 2021

Published: 18 January 2021

Publisher's Note: MDPI stays neutral with regard to jurisdictional claims in published maps and institutional affiliations.

Copyright: (c) 2021 by the authors. Licensee MDPI, Basel, Switzerland. This article is an open access article distributed under the terms and conditions of the Creative Commons Attribution (CC BY) license (https:// creativecommons.org/licenses/by/ $4.0 /)$.

\begin{abstract}
This study examined the effects of high-impact weight-bearing exercise on bone mineral density (BMD) and bone metabolic markers in middle-aged premenopausal women. Forty middleaged premenopausal women were initially enrolled, but thirty-one participants ( $40.34 \pm 3.69$ years) completed in the study. The subjects were randomly divided into two groups including the highimpact weight-bearing exercise group $(\mathrm{HWE}, \mathrm{n}=14)$ and control group $(\mathrm{CON}, \mathrm{n}=17)$. The HWE group participated in the exercise for $50 \mathrm{~min}$ a day, three days per week for four months, while the CON group maintained their regular lifestyle. The HWE program included 10 different high-impact weight-bearing exercises such as jumping and running. BMD was measured using DXA (Hologic, QDR 4500W, Marlborough, MA, USA). The bone metabolic markers including serum 25-(OH) D, intact parathyroid hormone (PTH), osteoprotegerin (OPG), osteopontin (OPN), receptor activator of nuclear factor $\mathrm{kB}$ ligand (RANKL), osteocalcin (OC), C-terminal telopeptide of type 1 collagen (CTX), and calcium were analyzed. The results showed that the BMDs of femur, lumbar, and forearm did not significantly change during the intervention period in both the HWE and CON groups. A significant decrease in bone formation markers such as OC $\left(F=10.514, p=0.003, \eta_{\mathrm{p}}{ }^{2}=0.266\right)$ and an increase in bone resorption marker including CTX $\left(F=8.768, p=0.006, \eta_{p}{ }^{2}=0.232\right)$ were found only in the $\mathrm{CON}$ group, while these values did not change in the HWE group. There was a significant increase in serum $25-(\mathrm{OH}) \mathrm{D}\left(F=4.451, p=0.044, \eta_{\mathrm{p}}{ }^{2}=0.133\right)$ in the HWE group. Our findings suggest that four months of HWE is not sufficient to improve BMD and bone metabolic markers, but this impact exercise program may prevent the age-associated changes in bone turnover markers in middle-aged premenopausal women.
\end{abstract}

Keywords: high-impact weight-bearing exercise; bone mineral density; bone metabolic markers; serum 25-(OH) D; middle-aged premenopausal women

\section{Introduction}

Physical inactivity adversely affects some health conditions including osteoporosis, neurological diseases, type 2 diabetes, obesity, cardiovascular diseases (CVD), and sarcopenia [1]. In particular, osteoporosis has been reported worldwide as a serious public health problem in recent years. It is estimated that over 200 million women suffer from this disease, and there are approximately 75 million people experiencing osteoporosis in the USA, Europe, and Japan [2-6]. Bone loss is commonly accompanied by aging, which slowly increases bone loss after the age of 35 years, and the process of osteoporosis rises at an exponential rate after menopause [7]. Elderly women with hip fractures have a higher 
mortality rate of 10 to $20 \%$ than their counterparts, and osteoporosis has a much higher prevalence rate in women over 45 years of age than other diseases including breast cancer, diabetes mellitus, myocardial infarction [8,9]. Furthermore, the previous study suggested that the incidence of hip fracture would increase by $310 \%$ in men and $240 \%$ in women by 2050 due to the growth of the aging population and vulnerability to hip fracture with age [10]. Due to these clinical prescriptions, the diagnosis, consequences, monitoring of treatment, and therapy for osteoporosis are of crucial importance [11].

Analyzing bone turnover markers, an index of bone metabolism, are novel tools that detect bone remodeling dynamics including bone formation and resorption [12]. Bone remodeling is regulated by the activation of osteoclasts and osteoblasts and these biomarkers reflect the current status of bone turnover rate [11]. Bone turnover rate can be examined by analyzing bone formation markers such as bone-specific alkaline phosphatase, procollagen type $1 \mathrm{~N}$ propeptide, and osteocalcin (OC) and bone resorption markers including the N-terminal telopeptide of type 1 collagen and C-terminal telopeptide of type 1 collagen (CTX) [13]. It is also actively regulated by various factors such as osteopontin $(\mathrm{OPN})$, osteoprotegerin (OPG), receptor activator of nuclear factor $\kappa \mathrm{B}$ ligand (RANKL), parathyroid hormone (PTH), and vitamin D involved in the bone formation process [14-16]. RANKL is produced in osteoblasts and stromal cells and is the critical factor for the activation of mature osteoclasts and differentiation of monocyte-macrophage osteoclasts, which are precursors to multinucleated osteoclasts [10]. In contrast, OPG, one of the primary regulators of osteoclast-mediated bone resorption, is a factor observed in bone tissue [16]. OPN is a glycoprotein of the extracellular matrix of bone tissues that bind to hydroxyapatite and calcium, and it has been proposed as a mediator of atherosclerosis pathogenic pathways [16]. Vitamin D deficiency may be cause hyperthyroidism, resulting in increased bone turnover and bone loss [17,18]. According to the National Academy of Medicine, vitamin D deficient is defined as a level of serum $25(\mathrm{OH}) \mathrm{D}$ of $12 \mathrm{ng} \cdot \mathrm{mL}^{-1}$, whereas a level of 12 to $<20 \mathrm{ng} \cdot \mathrm{mL}^{-1}$ is considered to be inadequate, and a level of $\geq 20 \mathrm{ng} \cdot \mathrm{mL}^{-1}$ defines vitamin D sufficiency [19]. Additionally, the elevated circulatory PTH levels may have negative effects [20]. However, several confounding factors determine the cause of the inverse relationship between serum $25(\mathrm{OH}) \mathrm{D}$ and PTH, and consistent results are not found in previous studies [20,21]. Calcium plays an important role as an essential nutrient for bone health [22]. However, previous studies have shown an excessively increased serum calcium relationship with an increased risk of cardiovascular disease [23-25]. These causes require an understanding of the potential impacts of serum calcium on bone health and care for health benefits. Thus, exploring the changes in bone turnover markers in response to exercise is essential for identifying mechanisms of the bone response [26].

The mechanical loading of high-impact physical activities (e.g., jumping and running) has been shown to increase bone mass in humans [27]. Additionally, impact activities such as high-intensity weight-bearing and jumping are more likely to be osteogenic than non-weight-bearing or low-impact activities such as swimming and walking [28]. Metaanalysis studies have shown that dynamic and resistance exercises are appropriate for increasing bone mineral density (BMD) in middle-aged women [29,30]. The majority of female participants that have been studied in impact exercise interventions were postmenopausal women because they represent the most popular group in which osteoporosis is manifested. Therefore, studies on pre-menopausal females are perceived to be in the greatest need [31-35]. However, a relatively small number of studies utilizing impact exercise training have targeted pre-menopausal women with combinations of supervised and home-based exercise sessions, which resulted in small positive effects $[29,30,36]$. Analyzing the bone turnover rate, an index of bone metabolism, plays an important role in understanding the biochemical activities in the bone and the changes in these markers can increase bone mineral density after weight-bearing exercise. It has been reported that acute, short-, and long-term exercise training increased the regulation bone remodeling markers such as OC, CTX, OPN, OPG, RANKL, PTH, and calcium [37-40]. Scott et al. [39] reported 
that acute weight-bearing exercise training increased serum levels of OPG, calcium, and PTH. Lester et al. [40] reported that combined aerobic and resistance exercise training for eight weeks significantly increased serum levels of OC in young women. Nevertheless, impact exercise training has not been explicitly directed at adult pre-menopausal women, despite the significant risk of developing osteoporosis after menopause.

Therefore, our study aimed to examine the effects of four months of high-impact weight-bearing exercise on BMD and bone metabolic markers in middle-aged premenopausal women.

\section{Materials and Methods}

\subsection{Subjects}

The power test was performed using G*Power 3.1.9.2 (Franz Faul, University of Kiel, Kiel, Germany) at the effect size of 0.3 , the significant level of $0.05(\alpha=0.05)$, and the power of 0.8 for all statistical tests. $G^{*}$ Power showed that 24 subjects had sufficient power for this study. Forty middle-aged premenopausal women aged 33-47 years were initially enrolled in the study. The exclusion criteria were specified as follows: (1) participated in regular exercise within the last three months; (2) users of pharmaceutical agents that directly affect bone, hypertension, and hyperlipidemia; and (3) blood pressure $\geq 140 / 90 \mathrm{mmHg}$. The subjects were randomly divided into two groups including HWE and CON. However, nine dropped out due to personal reasons and pregnancy; thus, thirty-one subjects completed the study (HWE: $\mathrm{n}=14, \mathrm{CON}: \mathrm{n}=17$ ) (Table 1 ). All proceedings of the study were approved by the Institutional Review Board of Kyung Hee University (KHGIRB-19-226) and were conducted according to the Declaration of Helsinki.

Table 1. Physical characteristics and nutritional intake of subjects.

\begin{tabular}{|c|c|c|c|c|c|c|c|}
\hline \multirow{2}{*}{ Variables } & \multicolumn{2}{|c|}{ HWE } & \multicolumn{2}{|c|}{ CON } & \multicolumn{3}{|c|}{$F$-Value } \\
\hline & Pre & Post & Pre & Post & Time & Group & Interaction \\
\hline Age (yrs) & $40.3 \pm 4.23$ & - & $40.4 \pm 3.31$ & - & & & \\
\hline Body height (cm) & $160.5 \pm 4.74$ & - & $161.2 \pm 5.04$ & - & & & \\
\hline Body weight (kg) & $58.8 \pm 10.98$ & $57.9 \pm 9.43$ & $62.8 \pm 11.73$ & $63.3 \pm 12.16$ & 0.148 & 1.377 & 1.875 \\
\hline BMI $\left(\mathrm{kg} \cdot \mathrm{m}^{-2}\right)$ & $22.7 \pm 3.62$ & $22.3 \pm 3.14$ & $24.1 \pm 4.14$ & $24.3 \pm 4.46$ & 0.277 & 1.409 & 2.137 \\
\hline $\begin{array}{c}\text { Total caloric intake } \\
\text { (Kcal) }\end{array}$ & $2151.20 \pm 487.94$ & $2027.71 \pm 636.44$ & $2328.61 \pm 640.41$ & $2274.09 \pm 582.72$ & 0.632 & 1.353 & 0.095 \\
\hline Carbohydrate (g) & $293.29 \pm 79.16$ & $260.95 \pm 89.44$ & $297.46 \pm 86.66$ & $294.98 \pm 85.55$ & 1.409 & 0.497 & 1.036 \\
\hline Fat $(\mathrm{g})$ & $72.75 \pm 19.01$ & $73.82 \pm 23.36$ & $83.69 \pm 25.82$ & $80.00 \pm 26.35$ & 0.065 & 1.495 & 0.215 \\
\hline Protein $(\mathrm{g})$ & $98.08 \pm 29.89$ & $92.35 \pm 29.98$ & $113.30 \pm 40.46$ & $102.07 \pm 31.60$ & 1.665 & 1.498 & 0.175 \\
\hline Vitamin D (ug) & $5.18 \pm 4.47$ & $4.57 \pm 2.84$ & $4.76 \pm 2.26$ & $6.02 \pm 5.30$ & 0.109 & 0.260 & 0.900 \\
\hline Calcium (mg) & $878.26 \pm 242.49$ & $854.96 \pm 346.25$ & $1051.38 \pm 474.55$ & $995.38 \pm 575.03$ & 0.224 & 1.352 & 0.038 \\
\hline Magnesium (mg) & $163.6 \pm 80.95$ & $136.60 \pm 53.77$ & $124.24 \pm 51.53$ & $134.56 \pm 63.81$ & 0.270 & 1.650 & 1.350 \\
\hline
\end{tabular}

Values are expressed as mean \pm SD. HWE: high-impact weight-bearing exercise group, CON: control group, BMI: body mass index.

\subsection{High-Impact Weight-Bearing Exercise Program}

The training group performed the HWE program for 50 min a day (10:30 a.m.11:20 a.m.), three days per week for four months. The training program was composed of $10 \mathrm{~min}$ of warm-up, $30 \mathrm{~min}$ of HWE, and $10 \mathrm{~min}$ of cool-down. The HWE comprised of the clap, walking, jumping burpee, jumping squat, running in place, wall press, bench stepping, jumping lunge, jumping jack, and push up [30]. The exercise intensity including exercise time increased progressively every four week period. The training intensity was set at $60-80 \%$ (mean: $136.9 \pm 9.03$ beat $/ \mathrm{min}$, range: $123-180$ beat $/ \mathrm{min}$ ) of the heart rate reserve (HRR) and monitored every day by using a potable heart rate monitor (Polar RS400, Polar Electro Oy, Kempele, Finland). The detailed training program is shown in Table 2. 
Table 2. High-impact weight-bearing exercise program for the four-months of the study.

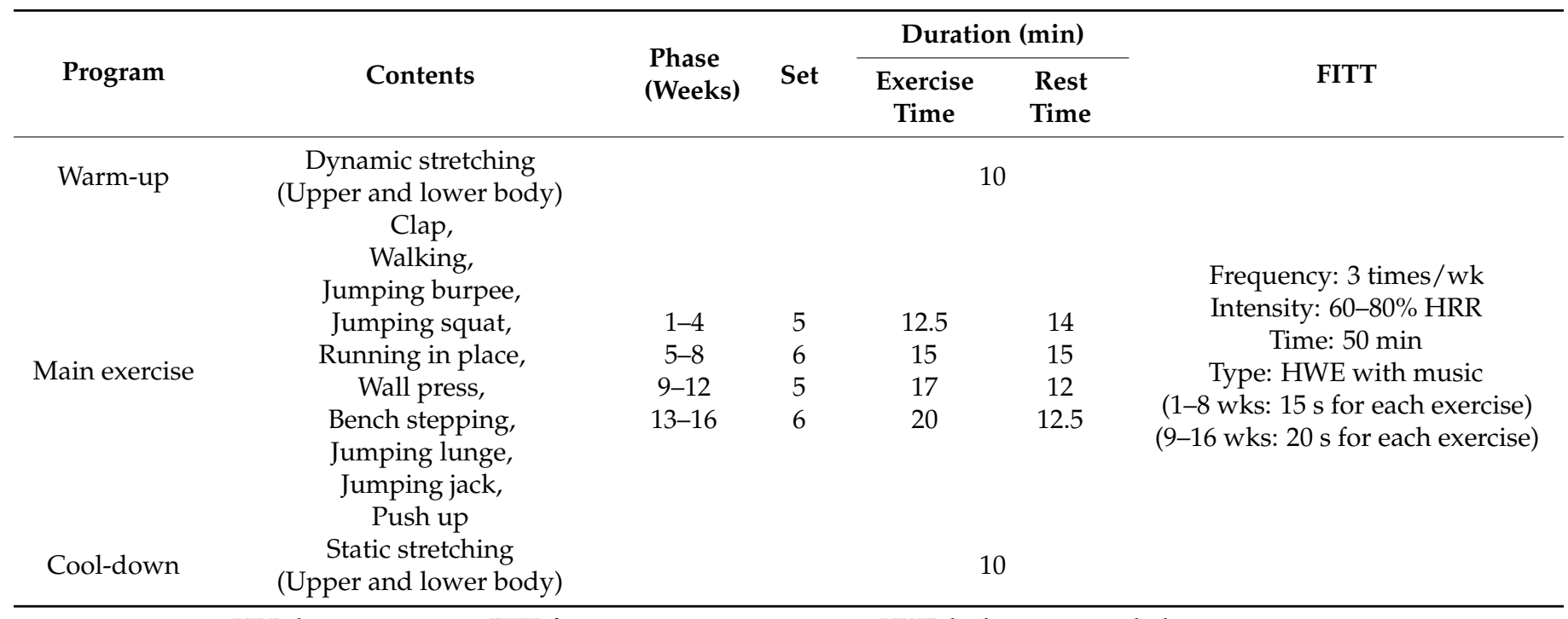

HRR: heart rate reserve, FITT: frequency, intensity, time, type, HWE: high-impact weight-bearing exercise.

\subsection{Anthropometric Measurements}

The body height and body weight were measured, and body mass index (BMI) was calculated by dividing body weight $(\mathrm{kg})$ by the square of body height $\left(\mathrm{m}^{2}\right)$. Body height was measured using a stadiometer to the nearest $0.1 \mathrm{~cm}$ (T.K.K. 11253, Takei Scientific Ins Co., Tokyo, Japan). Body weight was measured using a balance beam scale (Seca 700, Seca Co., Hamburg, Germany) to the nearest $0.1 \mathrm{~kg}$.

\subsection{Bone Mineral Density}

BMD was measured using dual-energy $x$-ray absorptiometry (DXA), with a Hologic QDR 4500W bone densitometer (Hologic, Marlborough, MA, USA). All participants were scanned at three different sites of the BMD (e.g., femur, lumbar, and forearm). The same technician performed all tests. The intra-class correlation coefficient (ICC) was measured (femur BMD: 0.997; lumbar BMD: 0.990; forearm BMD: 0.987) [41].

\subsection{Bone Metabolic Markers}

Blood samples were collected before and after the four-month intervention period. Participants arrived at the laboratory in the morning between 08:30 a.m. and 09:30 a.m. after $12 \mathrm{~h}$, overnight fasting, and avoiding severe physical activity or training the night before. Venous blood samples were taken $5 \mathrm{~mL}$ at the antecubital vein by a medical laboratory technologist and separated into each serum separate tube. The clotting of blood was separated using centrifugation with $3000 \mathrm{rpm}$ for $15 \mathrm{~min}$. The samples obtained were stored at $-80^{\circ} \mathrm{C}$ until analysis.

Serum 25-(OH) D was measured by a chemiluminescence microparticle immunoassay (CMIA) method (Architect i2000SR, Abbott, Singapore) with an ARCHITECT 25-(OH) vitamin D kit (Abbott Diagnostics, Lake Forest, IL, USA). The electrochemiluminescence immunoassay (ECLIA) method (E170, Roche, Germany) was used for intact PTH and CTX with an Elecsys PTH kit (Roche, Germany) and $\beta$-CrossLaps/serum kit (Roche, Germany). Bone metabolic markers including OPG, RANKL, and OPN were measured (VERSA Max, Molecular Device, Sunnyvale, CA, USA) by an enzyme-linked immunosorbent assay (ELISA) with OPG kit (ICL, Portland, OR, USA), RANKL kit (sRANKL ELISA, Immundiagnostik, Germany), and OPN kit (ICL, Portland, OR, USA). A radioimmunoassay (RIA) method (COBRA 5010 Quantum, USA) was used for analyzing OC, a marker of bone formation, with an OC kit (BRAHMS, Berlin, Germany). Calcium was measured by a homogeneous enzymatic colorimetric assay (HECA) method (c702, Germany) with a Calcium Gen.2 (Roche, Germany). The blood analysis was performed at the expertized 
research laboratory (Green Cross LabCell, Korea). The company is certified by the Korean Board for Accreditation and Conformity assessment.

\subsection{Nutritional Intake}

The dietary intake was assessed by three-day dietary records including twice on weekdays and once at the weekend in the first and the last weeks of the intervention. All data were analyzed by a computerized nutrient-intake assessment software program (CAN-PRO 4.0, Korean Nutrition Society, Seoul, Korea). The participants were instructed to maintain the same macronutrient distribution throughout the study.

\subsection{Statistical Analysis}

Statistical analyses were performed by using SAS software version 9.4 (SAS Institute, Cary, NC, USA). The mean, standard deviation, and 95\% confidence interval (CI) were calculated. The normality of distribution of all dependent variables was verified using the Kolmogorov-Smirnov test. Two-way repeated-measures ANOVA was applied to determine the interaction effect for the group by the time during the intervention. If any significant interaction or main effects were observed, the independent $t$-test and paired t-test were applied to analyze the significant differences within groups and between groups. The effect size was computed as partial eta-squared values $\left(\eta_{\mathrm{p}}{ }^{2}\right.$; small: $\geq 0.01$, medium: $\geq 0.06$, large: $\geq 0.14$ ) [42]. The statistical significance level was set at 0.05 .

\section{Results}

\subsection{Bone Mineral Density}

There were no significant interaction effects for group by time on femur $\mathrm{BMD}(F=0.458$, $\left.p=0.504, \eta_{\mathrm{p}}^{2}=0.016\right)$, lumbar BMD $\left(F=0.009, p=0.925, \eta_{\mathrm{p}}^{2}=0.000\right)$, and forearm BMD $\left(F=0.048, p=0.827, \eta_{\mathrm{p}}^{2}=0.002\right)$ during the intervention period (Table 3$)$.

Table 3. Changes of bone mineral density (BMD) between pre- and post-tests in middle-aged premenopausal women.

\begin{tabular}{|c|c|c|c|c|c|c|c|}
\hline \multirow{2}{*}{ Variables } & \multicolumn{2}{|c|}{ HWE } & \multicolumn{2}{|c|}{ CON } & \multicolumn{3}{|c|}{$\begin{array}{c}F \text {-Value } \\
\left(\eta p^{2}\right)\end{array}$} \\
\hline & $\begin{array}{c}\text { Pre } \\
(95 \% \mathrm{CI})\end{array}$ & $\begin{array}{c}\text { Post } \\
(95 \% \text { CI })\end{array}$ & $\begin{array}{c}\text { Pre } \\
(95 \% \text { CI })\end{array}$ & $\begin{array}{c}\text { Post } \\
(95 \% \text { CI })\end{array}$ & Time & Group & Interaction \\
\hline $\begin{array}{l}\text { Femur BMD } \\
\quad\left(\mathrm{g} / \mathrm{cm}^{2}\right)\end{array}$ & $\begin{array}{c}0.891 \pm 0.103 \\
(0.838-0.946)\end{array}$ & $\begin{array}{c}0.895 \pm 0.103 \\
(0.842-0.950)\end{array}$ & $\begin{array}{c}0.898 \pm 0.109 \\
(0.846-0.952)\end{array}$ & $\begin{array}{c}0.898 \pm 0.113 \\
(0.846-0.952)\end{array}$ & $\begin{array}{c}0.515 \\
(0.017)\end{array}$ & $\begin{array}{c}0.015 \\
(0.001)\end{array}$ & $\begin{array}{c}0.458 \\
(0.016)\end{array}$ \\
\hline Lumbar BMD & $1.036 \pm 0.158$ & $1.036 \pm 0.167$ & $1.009 \pm 0.111$ & $1.009 \pm 0.112$ & 0.003 & 0.290 & 0.009 \\
\hline$\left(\mathrm{g} / \mathrm{cm}^{2}\right)$ & $(0.956-1.122)$ & $(0.952-1.126)$ & $(0.957-1.062)$ & $(0.958-1.064)$ & $(0.000)$ & (0.010) & $(0.000)$ \\
\hline $\begin{array}{l}\text { Forearm BMD } \\
\qquad\left(\mathrm{g} / \mathrm{cm}^{2}\right)\end{array}$ & $\begin{array}{l}0.563 \pm 0.036 \\
(0.544-0.584)\end{array}$ & $\begin{array}{l}0.560 \pm 0.037 \\
(0.541-0.581)\end{array}$ & $\begin{array}{l}0.579 \pm 0.041 \\
(0.560-0.598)\end{array}$ & $\begin{array}{l}0.576 \pm 0.045 \\
(0.555-0.596)\end{array}$ & $\begin{array}{c}3.413 \\
(0.105)\end{array}$ & $\begin{array}{c}1.243 \\
(0.041)\end{array}$ & $\begin{array}{c}0.048 \\
(0.002)\end{array}$ \\
\hline
\end{tabular}

Values are expressed as mean \pm SD. 95\% CI: 95\% confidence interval, BMD: bone mineral density, HWE: high-impact weight-bearing exercise, CON: control.

\subsection{Bone Metabolic Markers}

There were significant interaction effects for group by time on serum $25-(\mathrm{OH}) \mathrm{D}$ $\left(F=4.451, p=0.044, \eta_{\mathrm{p}}{ }^{2}=0.133\right)$ and $\mathrm{OC}\left(F=10.514, p=0.003, \eta_{\mathrm{p}}{ }^{2}=0.266\right)($ Figures 1 and 2$)$. The post-test showed that serum $25-(\mathrm{OH}) \mathrm{D}$ concentration was increased significantly following the four-months of high impact weight-bearing exercise $(p<0.01)$, while no significant change was found in the CON group. OC level was not changed in the HWE group, but this value decreased significantly in the CON group $(p<0.05)$. There were significant time effects on intact PTH $\left(F=4.447, p=0.044, \eta_{\mathrm{p}}{ }^{2}=0.133\right)$, OPN $(F=5.480$, $\left.p=0.026, \eta_{\mathrm{p}}^{2}=0.159\right), \operatorname{CTX}\left(F=8.768, p=0.006, \eta_{\mathrm{p}}{ }^{2}=0.232\right)$, and calcium $(F=7.986$, $\left.p=0.008, \eta_{\mathrm{p}}^{2}=0.216\right)($ Table 4$)$. 


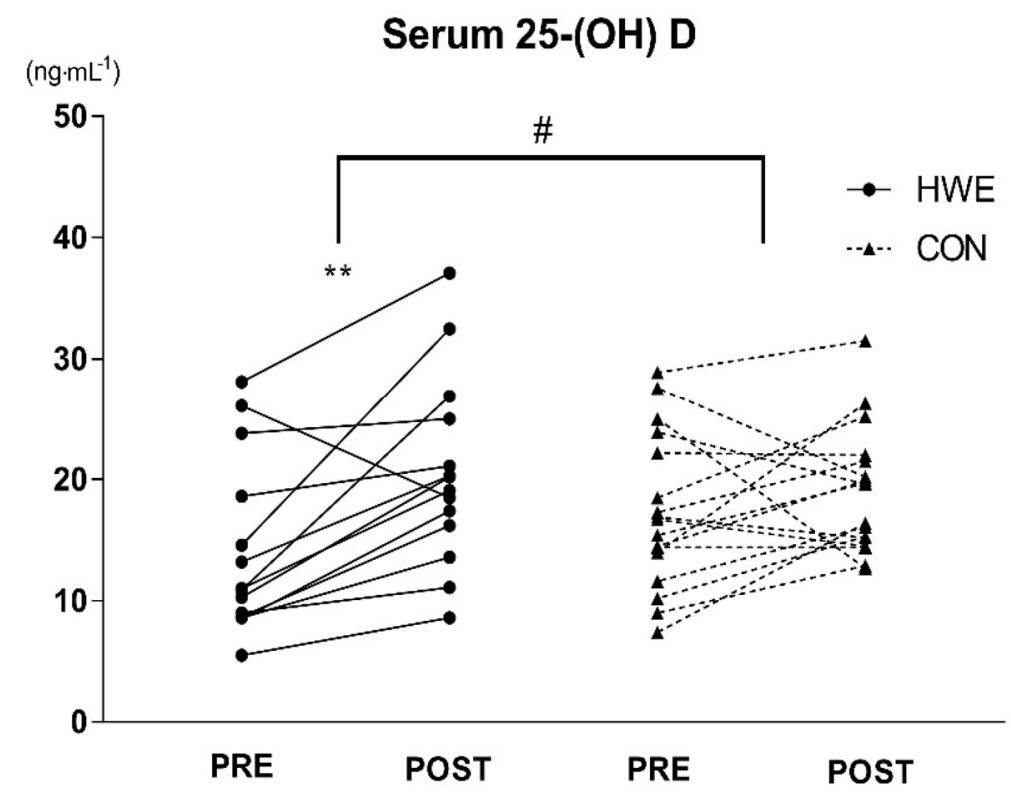

Figure 1. Serum 25- $(\mathrm{OH}) \mathrm{D}$ before and after the four-month exercise program. For serum 25- $(\mathrm{OH}) \mathrm{D}$, statistical analyses revealed an increase between pre- and post-tests in the HWE group. HWE: highimpact weight-bearing exercise, CON: control. Significant difference between pre- and post-tests, ** $p<0.01$. Significant interaction effect, ${ }^{\#} p<0.05$.

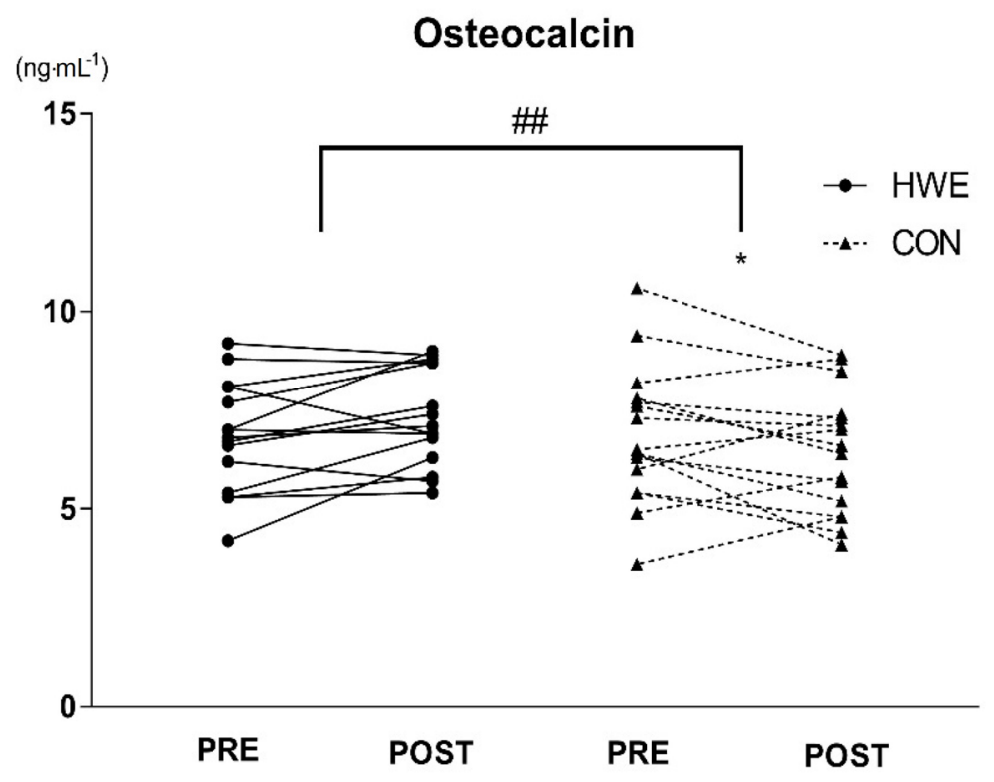

Figure 2. Osteocalcin before and after the four-month exercise program. For osteocalcin, statistical analyses revealed a decrease between pre- and post-tests in the CON group. HWE: high-impact weight-bearing exercise, CON: control. Significant difference between pre- and post-tests, ${ }^{*} p<0.05$. Significant interaction effect, ${ }^{\# \#} p<0.01$. 
Table 4. Changes in bone metabolic markers between pre- and post-tests in middle-aged premenopausal women.

\begin{tabular}{|c|c|c|c|c|c|c|c|}
\hline \multirow{2}{*}{ Variables } & \multicolumn{2}{|c|}{ HWE } & \multicolumn{2}{|c|}{$\mathrm{CON}$} & \multicolumn{3}{|c|}{$\begin{array}{c}F \text {-value } \\
\left(\eta p^{2}\right)\end{array}$} \\
\hline & $\begin{array}{c}\text { Pre } \\
(95 \% \text { CI })\end{array}$ & $\begin{array}{c}\text { Post } \\
(95 \% \text { CI })\end{array}$ & $\begin{array}{c}\text { Pre } \\
(95 \% \mathrm{CI})\end{array}$ & $\begin{array}{c}\text { Post } \\
(95 \% \text { CI })\end{array}$ & Time & Group & Interaction \\
\hline $\begin{array}{l}25-(\mathrm{OH}) \mathrm{D} \\
\left(\mathrm{ng} \cdot \mathrm{mL}^{-1}\right)\end{array}$ & $\begin{array}{c}14.1 \pm 7.24 \\
(9.9-18.2)\end{array}$ & $\begin{array}{c}20.5 \pm 7.81 \\
(16.0-25.1)\end{array}$ & $\begin{array}{l}17.3 \pm 6.37 \\
(13.9-20.5)\end{array}$ & $\begin{array}{l}19.0 \pm 5.17 \\
(16.4-21.7)\end{array}$ & $\begin{array}{c}13.559 \# \# \\
(.319)\end{array}$ & $\begin{array}{c}0.158 \\
(0.005)\end{array}$ & $\begin{array}{l}4.451^{\#} \\
(0.133)\end{array}$ \\
\hline Intact PTH & $36.6 \pm 9.00$ & $42.6 \pm 8.73^{*}$ & $36.5 \pm 10.18$ & $38.9 \pm 8.85$ & $4.447^{\#}$ & 0.498 & 0.800 \\
\hline$\left(\mathrm{pg} \cdot \mathrm{mL}^{-1}\right)$ & $(31.4-41.8)$ & $(37.6-47.7)$ & $(31.2-41.7)$ & $(34.4-43.5)$ & $(0.133)$ & $(0.017)$ & $(0.027)$ \\
\hline OPG & $5.7 \pm 0.80$ & $5.1 \pm 1.26$ & $5.6 \pm 1.26$ & $5.3 \pm 1.65$ & 3.911 & 0.021 & 0.173 \\
\hline$\left(\mathrm{pmol} \cdot \mathrm{L}^{-1}\right)$ & (5.2-6.1) & $(4.4-5.8)$ & $(5.0-6.3)$ & $(4.4-6.1)$ & $(0.119)$ & $(0.001)$ & $(0.006)$ \\
\hline $\begin{array}{c}\text { RANKL } \\
\left(\mathrm{pmol} \cdot \mathrm{L}^{-1}\right)\end{array}$ & $\begin{array}{c}286.9 \pm 178.95 \\
(183.6-390.3)\end{array}$ & $\begin{array}{c}277.8 \pm 186.06 \\
(170.3-325.2)\end{array}$ & $\begin{array}{c}199.6 \pm 108.34 \\
(143.9-255.3)\end{array}$ & $\begin{array}{c}224.5 \pm 124.01 \\
(160.7-288.2)\end{array}$ & $\begin{array}{c}0.225 \\
(0.008)\end{array}$ & $\begin{array}{c}1.868 \\
(0.061)\end{array}$ & $\begin{array}{l}1.062 \\
(0.035)\end{array}$ \\
\hline OPN & $63.2 \pm 31.97$ & $50.1 \pm 37.46$ * & $51.2 \pm 15.56$ & $47.8 \pm 20.78$ & $5.480^{\#}$ & 0.622 & 1.867 \\
\hline$\left(\mathrm{ng} \cdot \mathrm{mL}^{-1}\right)$ & $(44.7-81.6)$ & $(28.5-71.8)$ & $(43.2-59.2)$ & $(37.1-58.5)$ & $(0.159)$ & $(0.021)$ & $(0.060)$ \\
\hline $\begin{array}{l}\text { Osteocalcin } \\
\left(\mathrm{ng} \cdot \mathrm{mL}^{-1}\right)\end{array}$ & $\begin{array}{c}6.8 \pm 1.46 \\
(6.0-7.7)\end{array}$ & $\begin{array}{c}7.3 \pm 1.29 \\
(6.6-8.1)\end{array}$ & $\begin{array}{c}6.9 \pm 1.69 \\
(6.0-7.8)\end{array}$ & $\begin{array}{c}6.2 \pm 1.50 * \\
(5.5-7.0)\end{array}$ & $\begin{array}{c}0.132 \\
(0.005)\end{array}$ & $\begin{array}{l}1.068 \\
(0.036)\end{array}$ & $\begin{array}{c}10.514^{\# \#} \\
(0.266)\end{array}$ \\
\hline CTX & $0.24 \pm 0.10$ & $0.28 \pm 0.09$ & $0.26 \pm 0.16$ & $0.31 \pm 0.14$ * & $8.768^{\# \#}$ & 0.296 & 0.018 \\
\hline$\left(\mathrm{ng} \cdot \mathrm{mL}^{-1}\right)$ & $(0.19-0.30)$ & $(0.23-0.34)$ & $(0.18-0.35)$ & $(0.23-0.38)$ & $(0.232)$ & $(0.010)$ & $(0.001)$ \\
\hline Calcium & $9.7 \pm 0.46$ & $9.5 \pm 0.40$ & $9.8 \pm 0.29$ & $9.5 \pm 0.29^{* *}$ & 7.986 \#\# & 0.204 & 0.442 \\
\hline$\left(\mathrm{mg} \cdot \mathrm{dL}^{-1}\right)$ & $(9.5-10.0)$ & $(9.3-9.8)$ & $(9.7-10.0)$ & $(9.4-9.7)$ & $(0.216)$ & $(0.007)$ & $(0.015)$ \\
\hline
\end{tabular}

Values are expressed as mean \pm SD. 95\% CI: 95\% confidence interval, HWE: high-impact weight-bearing exercise, CON: control, PTH: parathyroid hormone, OPG: osteoprotegerin, RANKL: receptor activator of nuclear factor kB ligand, OPN: osteopontin, CTX: C-terminal telopeptide of type 1 collagen. Significant interaction or main effect, ${ }^{\#} p<0.05,{ }^{\# \#} p<0.01$. Significant difference between pre- and post-tests, ${ }^{*} p<0.05,{ }^{* *} p<0.01$.

\section{Discussion}

The present study examined the effects of four months of HWE on BMD and bone metabolic markers in middle-aged premenopausal women. Our main findings showed that a significant decrease in OC and an increase in CTX were found only in the CON group while these values did not change in the HWE group. However, four months of HWE were not sufficient to improve BMD in middle-aged premenopausal women.

Substantial empirical evidence has shown that resistance and step exercise have several benefits, which work as non-pharmacological interventions for the improvement of bone health in children/adolescents, adulthood, and the elderly [31,43]. However, the effects of high-impact exercise on BMD in middle-aged pre-menopausal women remain unknown [36]. The present study showed no significant effects on femur, lumbar, and forearm BMD after four-month of high-impact weight-bearing exercise. The International and National Osteoporosis Foundation, and other organizations recommend weight-bearing exercises to prevent osteopenia and osteoporosis [44]. There are different types of body weight-bearing exercises including high-impact exercises such as running and jumping as well as low-impact exercises such as body weight training, water aerobics, and walking [44]. It has been recently reported that trochanter and femoral neck BMD were significantly improved after high-impact weight-bearing exercise in pre-menopausal women [30]. Additionally, high-impact weight-bearing and resistance training either in combination or alone, induced gains in BMD by $1-2 \%$ at the femoral neck and lumbar spine with a minimal effect on other body sites in pre-menopausal and post-menopausal women [45]. Similar results in other studies have found that high-impact exercise for 12 months ( 3 times/week) resulted in a significant improvement in femoral neck BMD by $0.6-1.1 \%$ in pre-menopausal women $[46,47]$. Although the present study did not show a significant change, there was a tendency where the femur BMD increased following four months of HWE $(0.47 \%)$ without any improvement on other sites of the body. Foster and Armstrong [48] reported that a bone remodeling cycle takes about 3-4 months and a minimum of 6-8 months is required for the bone to reach a new, measurable steady-state bone mass. Therefore, the absence of the significant improvement in BMD is likely due to the insufficient duration of an exercise intervention to promote bone formation in the present study. In fact, combined- 
impact exercise protocols lasting more than six months (duration: 30-60 min; frequency: $\geq 3$ days/week) have been recommended for greater bone health benefits [49]. Moreover, adults might benefit from high-impact exercises, but previous studies have suggested that its effect might occur to a lesser extent than in children or adolescents [50]. In this study, the effect of four-months of high-impact weight-bearing exercise appeared to be none or small only in particular sites such as femur BMD in middle-aged premenopausal women.

Biochemical bone metabolic markers indicate changes in bone metabolism more quickly than changes in BMD, which are commonly used to monitor osteoporosis [51]. Additionally, bone metabolic markers could be used to evaluate the antiresorptive agents in the clinical diagnosis of osteoporosis and osteopenia [52]. One intended therapeutic aim of the antiresorptive therapy is to decrease levels of bone metabolic markers below the average reference range for pre-menopausal women [53]. Bone metabolic markers provide important information such as the rate of bone remodeling by changing bone formation and resorption, and the evaluation of these markers has been used in previous intervention studies to identify the effectiveness of exercise [54-56]. The results of our study showed that serum $25-(\mathrm{OH}) \mathrm{D}(60.22 \%, p<0.01)$, and intact PTH $(23.86 \%, p<0.05)$ were increased significantly in HWE between pre- and post-tests, whereas OPN $(-20.45 \%, p<0.05)$ was decreased significantly in HWE between pre- and post-tests. Furthermore, OC $(-7.89 \%$, $p<0.05)$ and calcium $(-2.99 \%, p<0.01)$ were decreased significantly in CON between pre- and post-tests, whereas CTX $(30.94 \%, p<0.05)$ was increased significantly in CON between pre- and post-tests. However, no significant interaction effects were found on other markers including intact PTH, OPG, RANKL, and OPN.

Vitamin D plays a critical role in promoting the intestinal absorption of phosphate and calcium [57], and participating in regular physical activity is a well-known stimulator of serum 25-(OH) D [58]. In accordance with our results, Josse et al. [55] reported that the serum 25-(OH) D increased significantly following 12 weeks of resistance training in young women, but the level of PTH was not significantly changed. It is an interesting result in the present study where the HWE group increased both vitamin D and PTH level after four-months of exercise intervention. Generally, serum calcium level is mediated by vitamin D and PTH [59] and the changes in these levels may increase or decrease the mineralization of bone. It is assumed that an increase in PTH level may help to maintain serum calcium level. In particular, our participants were healthy and had no bone-related disease, thus it is possible that PTH is increased for calcium homeostasis. Moghadasi and Siavashpour [56] reported that resistance circuit training for 12 weeks significantly increased PTH in healthy and sedentary young women, which agrees with the present result. Authors assumed that this increase in PTH after resistance training may promote anabolic activities in bone metabolism. However, it is difficult to explain the direct relations or physiological mechanism between the variables in the present study and conflicting results have been observed in previous studies. Pilch et al. [60] reported that Nordic walking training for six weeks significantly decreased serum 25- $(\mathrm{OH}) \mathrm{D}$ in post-menopausal women and Evans et al. [54] reported that a recruit training program for four-months significantly decreased serum $25-(\mathrm{OH}) \mathrm{D}$ in men, whereas these values remained at baseline levels in women. Vitamin $\mathrm{D}$ is an important factor for bone health, and its deficiency leads to osteoporosis and CVD in adults $[61,62]$. Moreover, physically inactive individuals have two times lower vitamin D levels than active adults [63]. Although it is difficult to determine the direct relations between HWE and increased serum 25- $(\mathrm{OH}) \mathrm{D}$, several studies support our results that increase in physical activity is an effective manner to maintain optimal vitamin D level in later life [64,65]. In this study, the serum 25-(OH) D increased from an inadequate level $\left(12-20 \mathrm{ng} \cdot \mathrm{mL}^{-1}\right)$ to a sufficient level $\left(\geq 20 \mathrm{ng} \cdot \mathrm{mL}^{-1}\right)$ in HWE.

Bone turnover markers provide information on important biochemical indicators such as bone resorption and bone formation in managing osteoporosis [66]. A significant association between bone turnover markers and the risk of fractures has been identified for females and males [67]. Mohr et al. [68] reported that soccer training for 15 weeks 
significantly increased plasma OC ( $37 \pm 15 \%)$ and CTX (42 $\pm 18 \%)$ in middle-aged premenopausal women. A significant increase in OC has also been observed in untrained young women following sixteen weeks of exercise intervention [69]. Additionally, exercise training caused augmentation in resting plasma OC and CTX in elderly sedentary men with no resistance training [70]. However, CTX has been shown to increase shortly or immediately after impact exercise [26]. Thus, impact exercise may have a high potential to improve bone health in the general population. Therefore, the above intervention studies and our study results indicate that impact exercise describes a feasible intervention modality in middle-aged premenopausal women.

Previous studies by Ferrucci et al. [71] and Fuller et al. [72] emphasized that changes in pro-inflammatory and anti-inflammatory cytokines have profound implications on agerelated bone loss. OPN acts through binding to integrin $\beta-3$, leading to a decrease in the cytoplasmic calcium concentration associated with osteoclast activation [10]. Humphries et al. [38] reported that participants who underwent whole-body vibration with or without the combination of resistance training for 16 weeks showed a significant decrease in OPN in young healthy women, which is consistent with the present findings. Thus, exercise training induces changes in bone metabolism faster than actual changes in BMD in middleaged premenopausal women. Therefore, it is important to monitor and stimulate bone metabolic markers to prevent osteoporosis before menopause in women, especially when considering a higher prevalence of osteoporosis after menopause.

\section{Limitation of the study}

In this study, there are some limitations that need to be considered. Although the present study is well designed with the randomized controlled trials, the relatively shortterm intervention period (four-months) may be a limit to confirming the longitudinal effects of high-impact weight-bearing exercise on BMD in middle-aged premenopausal women. However, the positive changes in bone metabolic markers such as OC and vitamin D may provide a potential benefit on bone health. In future study, a longer period of exercise intervention (more than six months) is needed to examine how changed bone metabolic markers are linked to the BMD changes.

\section{Conclusions}

The present study revealed that four months of HWE is not sufficient to improve BMD and bone metabolic markers, but this exercise program may prevent the age-associated changes in bone turnover markers in middle-aged premenopausal women.

Author Contributions: Conception and study design, S.-W.K. and J.-K.S.; Statistical analysis, S.-W.K. and J.-K.S.; Investigation, S.-W.K.; Data interpretation, S.-W.K., J.-K.S., M.-W.S., and H.-C.J.; Writingoriginal draft preparation, S.-W.K.; Writing-review and editing, H.-C.J., and J.-K.S.; Supervision, J.-K.S. All authors have read and approved the final manuscript.

Funding: This work was supported by the Ministry of Education of the Republic of Korea and the National Research Foundation of Korea (NRF-2019S1A5A2A01049721).

Institutional Review Board Statement: The study was conducted according to the guidelines of the Declaration of Helsinki, and approved by the Institutional Review Board of Kyung Hee University (KHGIRB-19-226).

Informed Consent Statement: Informed consent was obtained from all subjects involved in the study.

Conflicts of Interest: The authors declare no conflict of interest.

\section{References}

1. Hamilton, M.T.; Hamilton, D.G.; Zderic, T.W. Role of low energy expenditure and sitting in obesity, metabolic syndrome, type 2 diabetes, and cardiovascular disease. Diabetes 2007, 56, 2655-2667. [CrossRef]

2. Reginster, J.Y.; Burlet, N. Osteoporosis: A still increasing prevalence. Bone 2006, 38, S4-S9. [CrossRef] [PubMed]

3. Sweet, M.G.; Sweet, J.M.; Jeremiah, M.P.; Galazka, S.S. Diagnosis and treatment of osteoporosis. Am. Fam. Physician 2009, 79, 193-200. [PubMed] 
4. Tarride, J.E.; Hopkins, R.B.; Leslie, W.D.; Morin, S.; Adachi, J.D.; Papaioannou, A.; Bessette, L.; Brown, J.P.; Goeree, R. The burden of illness of osteoporosis in Canada. Osteoporos. Int. 2012, 23, 2591-2600. [CrossRef] [PubMed]

5. Kanis, J.A.; Cooper, C.; Rizzoli, R.; Reginster, J.Y. European guidance for the diagnosis and management of osteoporosis in postmenopausal women. Osteoporos. Int. 2019, 30, 3-44. [CrossRef]

6. Singer, A.; Exuzides, A.; Spangler, L.; O’Malley, C.; Colby, C.; Johnston, K.; Agodoa, I.; Baker, J.; Kagan, R. Burden of illness for osteoporotic fractures compared with other serious diseases among postmenopausal women in the United States. Mayo Clin. Proc. 2015, 90, 53-62. [CrossRef]

7. Burch, J.; Rice, S.; Yang, H.; Neilson, A.; Stirk, L.; Francis, R.; Holloway, P.; Selby, P.; Craig, D. Systematic review of the use of bone turnover markers for monitoring the response to osteoporosis treatment: The secondary prevention of fractures, and primary prevention of fractures in high-risk groups. Health Technol. Assess. 2014, 18, 1-180. [CrossRef]

8. Sambrook, P.; Cooper, C. Osteoporosis. Lancet 2006, 367, 2010-2018. [CrossRef]

9. Cummings, S.R.; Melton, L.J. Epidemiology and outcomes of osteoporotic fractures. Lancet 2002, 359, 1761-1767. [CrossRef]

10. Lampropoulos, C.E.; Papaioannou, I.; D'Cruz, D.P. Osteoporosis-A risk factor for cardiovascular disease? Nat. Rev. Rheumatol. 2012, 8, 587-598. [CrossRef]

11. Greenblatt, M.B.; Tsai, J.N.; Wein, M.N. Bone Turnover Markers in the Diagnosis and Monitoring of Metabolic Bone Disease. Clin. Chem. 2017, 63, 464-474. [CrossRef] [PubMed]

12. Shetty, S.; Kapoor, N.; Bondu, J.D.; Thomas, N.; Paul, T.V. Bone turnover markers: Emerging tool in the management of osteoporosis. Indian J. Endocrinol. Metab. 2016, 20, 846-852. [CrossRef] [PubMed]

13. Vasikaran, S.; Eastell, R.; Bruyère, O.; Foldes, A.J.; Garnero, P.; Griesmacher, A.; McClung, M.; Morris, H.A.; Silverman, S.; Trenti, T.; et al. Markers of bone turnover for the prediction of fracture risk and monitoring of osteoporosis treatment: A need for international reference standards. Osteoporos. Int. 2011, 22, 391-420. [CrossRef] [PubMed]

14. McCarty, M.F.; DiNicolantonio, J.J. The molecular biology and pathophysiology of vascular calcification. Postgrad. Med. 2014, 126, 54-64. [CrossRef] [PubMed]

15. Osako, M.K.; Nakagami, H.; Koibuchi, N.; Shimizu, H.; Nakagami, F.; Koriyama, H.; Shimamura, M.; Miyake, T.; Rakugi, H.; Morishita, R. Estrogen inhibits vascular calcification via vascular RANKL system: Common mechanism of osteoporosis and vascular calcification. Circ. Res. 2010, 107, 466-475. [CrossRef]

16. Lello, S.; Capozzi, A.; Scambia, G. Osteoporosis and cardiovascular disease: An update. Gynecol. Endocrinol. 2015, 31, 590-594. [CrossRef]

17. Ooms, M.E.; Lips, P.; Roos, J.C.; van der Vijgh, W.J.; Popp-Snijders, C.; Bezemer, P.D.; Bouter, L.M. Vitamin D status and sex hormone binding globulin: Determinants of bone turnover and bone mineral density in elderly women. J. Bone Min. Res. 1995, 10, 1177-1184. [CrossRef]

18. Kamineni, V.; Latha, A.P.; Ramathulasi, K. Association between serum 25-hydroxyvitamin D levels and bone mineral density in normal postmenopausal women. J. Midlife Health 2016, 7, 163-168. [CrossRef]

19. Ross, A.C.; Manson, J.E.; Abrams, S.A.; Aloia, J.F.; Brannon, P.M.; Clinton, S.K.; Durazo-Arvizu, R.A.; Gallagher, J.C.; Gallo, R.L.; Jones, G.; et al. The 2011 report on dietary reference intakes for calcium and vitamin D from the Institute of Medicine: What clinicians need to know. J. Clin. Endocrinol. Metab. 2011, 96, 53-58. [CrossRef]

20. Fisher, A.; Goh, S.; Srikusalanukul, W.; Davis, M. Elevated serum PTH is independently associated with poor outcomes in older patients with hip fracture and vitamin D inadequacy. Calcif. Tissue Int. 2009, 85, 301-309. [CrossRef]

21. Hao, L.; Carson, J.L.; Schlussel, Y.; Noveck, H.; Shapses, S.A. Vitamin D deficiency is associated with reduced mobility after hip fracture surgery: A prospective study. Am. J. Clin. Nutr. 2020, 112, 613-618. [CrossRef] [PubMed]

22. Liu, M.; Yao, X.; Zhu, Z. Associations between serum calcium, 25(OH)D level and bone mineral density in older adults. J. Orthop. Surg. Res. 2019, 14, 458. [CrossRef]

23. Reid, I.R.; Birstow, S.M.; Bolland, M.J. Calcium and Cardiovascular Disease. Endocrinol. Metab. (Seoul) 2017, 32, 339-349. [CrossRef] [PubMed]

24. Rohrmann, S.; Garmo, H.; Malmström, H.; Hammar, N.; Jungner, I.; Walldius, G.; Van Hemelrijck, M. Association between serum calcium concentration and risk of incident and fatal cardiovascular disease in the prospective AMORIS study. Atherosclerosis 2016, 251, 85-93. [CrossRef] [PubMed]

25. Larsson, S.C.; Burgess, S.; Michaëlsson, K. Association of Genetic Variants Related to Serum Calcium Levels with Coronary Artery Disease and Myocardial Infarction. JAMA 2017, 318, 371-380. [CrossRef]

26. Mezil, Y.A.; Allison, D.; Kish, K.; Ditor, D.; Ward, W.E.; Tsiani, E.; Klentrou, P. Response of Bone Turnover Markers and Cytokines to High-Intensity Low-Impact Exercise. Med. Sci. Sports Exerc. 2015, 47, 1495-1502. [CrossRef] [PubMed]

27. Kohrt, W.M.; Barry, D.W.; Schwartz, R.S. Muscle forces or gravity: What predominates mechanical loading on bone? Med. Sci. Sports Exerc. 2009, 41, 2050-2055. [CrossRef]

28. Kohrt, W.M.; Bloomfield, S.A.; Little, K.D.; Nelson, M.E.; Yingling, V.R. American College of Sports Medicine Position Stand: Physical activity and bone health. Med. Sci. Sports Exerc. 2004, 36, 1985-1996. [CrossRef]

29. Babatunde, O.O.; Forsyth, J.J.; Gidlow, C.J. A meta-analysis of brief high-impact exercises for enhancing bone health in premenopausal women. Osteoporos. Int. 2012, 23, 109-119. [CrossRef]

30. Zhao, R.; Zhao, M.; Zhang, L. Efficiency of jumping exercise in improving bone mineral density among premenopausal women: A meta-analysis. Sports Med. 2014, 44, 1393-1402. [CrossRef] 
31. Martyn-St James, M.; Carroll, S. A meta-analysis of impact exercise on postmenopausal bone loss: The case for mixed loading exercise programmes. Br. J. Sports Med. 2009, 43, 898-908. [CrossRef] [PubMed]

32. Nikander, R.; Sievanen, H.; Heinonen, A.; Daly, R.M.; Uusi-Rasi, K.; Kannus, P. Targeted exercise against osteoporosis: A systematic review and meta-analysis for optimising bone strength throughout life. BMC Med. 2010, 8, 47. [CrossRef] [PubMed]

33. Polidoulis, I.; Beyene, J.; Cheung, A.M. The effect of exercise on pQCT parameters of bone structure and strength in postmenopausal women-A systematic review and meta-analysis of randomized controlled trials. Osteoporos. Int. 2012, $23,39-51$. [CrossRef] [PubMed]

34. Marques, E.A.; Mota, J.; Carvalho, J. Exercise effects on bone mineral density in older adults: A meta-analysis of randomized controlled trials. Age 2012, 34, 1493-1515. [CrossRef] [PubMed]

35. Kelley, G.A.; Kelley, K.S.; Kohrt, W.M. Effects of ground and joint reaction force exercise on lumbar spine and femoral neck bone mineral density in postmenopausal women: A meta-analysis of randomized controlled trials. BMC Musculoskelet. Disord. 2012, 13, 177. [CrossRef] [PubMed]

36. Greenway, K.G.; Walkley, J.W.; Rich, P.A. Impact exercise and bone density in premenopausal women with below average bone density for age. Eur. J. Appl. Physiol. 2015, 115, 2457-2469. [CrossRef] [PubMed]

37. Yuan, Y.; Chen, X.; Zhang, L.; Wu, J.; Guo, J.; Zou, D.; Chen, B.; Sun, Z.; Shen, C.; Zou, J. The roles of exercise in bone remodeling and in prevention and treatment of osteoporosis. Prog. Biophys. Mol. Biol. 2016, 122, 122-130. [CrossRef]

38. Humphries, B.; Fenning, A.; Dugan, E.; Guinane, J.; MacRae, K. Whole-body vibration effects on bone mineral density in women with or without resistance training. Aviat. Space Environ. Med. 2009, 80, 1025-1031. [CrossRef]

39. Scott, J.P.; Sale, C.; Greeves, J.P.; Casey, A.; Dutton, J.; Fraser, W.D. The role of exercise intensity in the bone metabolic response to an acute bout of weight-bearing exercise. J. Appl. Physiol. 2011, 110, 423-432. [CrossRef]

40. Lester, M.E.; Urso, M.L.; Evans, R.K.; Pierce, J.R.; Spiering, B.A.; Maresh, C.M.; Hatfield, D.L.; Kraemer, W.J.; Nindl, B.C. Influence of exercise mode and osteogenic index on bone biomarker responses during short-term physical training. Bone 2009, 45, 768-776. [CrossRef]

41. Kim, S.W.; Jung, S.W.; Seo, M.W.; Park, H.Y.; Song, J.K. Effects of bone-specific physical activity on body composition, bone mineral density, and health-related physical fitness in middle-aged women. J. Exerc. Nutr. Biochem. 2019, 23, 36-42. [CrossRef] [PubMed]

42. Cohen, J. Statistical Power Analysis for the Behavioral Sciences; Academic Press: Cambridge, MA, USA, 2013.

43. Manske, S.L.; Lorincz, C.R.; Zernicke, R.F. Bone health: Part 2, physical activity. Sports Health 2009, 1, 341-346. [CrossRef] [PubMed]

44. Troy, K.L.; Mancuso, M.E.; Butler, T.A.; Johnson, J.E. Exercise Early and Often: Effects of Physical Activity and Exercise on Women's Bone Health. Int. J. Environ. Res. Public Health 2018, 15, 878. [CrossRef] [PubMed]

45. Sanudo, B.; de Hoyo, M.; Del Pozo-Cruz, J.; Carrasco, L.; Del Pozo-Cruz, B.; Tejero, S.; Firth, E. A systematic review of the exercise effect on bone health: The importance of assessing mechanical loading in perimenopausal and postmenopausal women. Menopause 2017, 24, 1208-1216. [CrossRef]

46. Vainionpaa, A.; Korpelainen, R.; Leppaluoto, J.; Jamsa, T. Effects of high-impact exercise on bone mineral density: A randomized controlled trial in premenopausal women. Osteoporos. Int. 2005, 16, 191-197. [CrossRef]

47. Niu, K.; Ahola, R.; Guo, H.; Korpelainen, R.; Uchimaru, J.; Vainionpaa, A.; Sato, K.; Sakai, A.; Salo, S.; Kishimoto, K.; et al. Effect of office-based brief high-impact exercise on bone mineral density in healthy premenopausal women: The Sendai Bone Health Concept Study. J. Bone Miner. Metab. 2010, 28, 568-577. [CrossRef]

48. Foster, C.; Armstrong, M. What types of physical activities are effective in developing muscle and bone strength and balance. J. Frailty Sarcopenia Falls 2018, 3, 58-65. [CrossRef]

49. Xu, J.; Lombardi, G.; Jiao, W.; Banfi, G. Effects of Exercise on Bone Status in Female Subjects, from Young Girls to Postmenopausal Women: An Overview of Systematic Reviews and Meta-Analyses. Sports Med. 2016, 46, 1165-1182. [CrossRef]

50. Santos, L.; Elliott-Sale, K.J.; Sale, C. Exercise and bone health across the lifespan. Biogerontology 2017, 18, 931-946. [CrossRef]

51. Delmas, P.D.; Hardy, P.; Garnero, P.; Dain, M. Monitoring individual response to hormone replacement therapy with bone markers. Bone 2000, 26, 553-560. [CrossRef]

52. de Papp, A.E.; Bone, H.G.; Caulfield, M.P.; Kagan, R.; Buinewicz, A.; Chen, E.; Rosenberg, E.; Reitz, R.E. A cross-sectional study of bone turnover markers in healthy premenopausal women. Bone 2007, 40, 1222-1230. [CrossRef] [PubMed]

53. Srivastava, A.K.; Vliet, E.L.; Lewiecki, E.M.; Maricic, M.; Abdelmalek, A.; Gluck, O.; Baylink, D.J. Clinical use of serum and urine bone markers in the management of osteoporosis. Curr. Med. Res. Opin. 2005, 21, 1015-1026. [CrossRef] [PubMed]

54. Evans, R.K.; Antczak, A.J.; Lester, M.; Yanovich, R.; Israeli, E.; Moran, D.S. Effects of a 4-month recruit training program on markers of bone metabolism. Med. Sci. Sports Exerc. 2008, 40, S660-S670. [CrossRef] [PubMed]

55. Josse, A.R.; Tang, J.E.; Tarnopolsky, M.A.; Phillips, S.M. Body composition and strength changes in women with milk and resistance exercise. Med. Sci. Sports Exerc. 2010, 42, 1122-1130. [CrossRef]

56. Moghadasi, M.; Siavashpour, S. The effect of 12 weeks of resistance training on hormones of bone formation in young sedentary women. Eur. J. Appl. Physiol. 2013, 113, 25-32. [CrossRef]

57. Pilch, W.; Tota, L.; Sadowska-Krepa, E.; Piotrowska, A.; Kepinska, M.; Palka, T.; Maszczyk, A. The Effect of a 12-Week Health Training Program on Selected Anthropometric and Biochemical Variables in Middle-Aged Women. Biomed. Res. Int. 2017, 2017, 9569513. [CrossRef] 
58. Scragg, R.; Camargo, C.A., Jr. Frequency of leisure-time physical activity and serum 25-hydroxyvitamin D levels in the US population: Results from the Third National Health and Nutrition Examination Survey. Am. J. Epidemiol. 2008, 168, 577-586. [CrossRef] [PubMed]

59. Dawson-Hughes, B.; Heaney, R.P.; Holick, M.F.; Lips, P.; Meunier, P.J.; Vieth, R. Estimates of optimal vitamin D status. Osteoporos. Int. 2005, 16, 713-716. [CrossRef]

60. Pilch, W.; Tyka, A.; Cebula, A.; Sliwicka, E.; Pilaczynska-Szczesniak, L.; Tyka, A. Effects of a 6-week Nordic walking training on changes in 25(OH)D blood concentration in women aged over 55. J. Sports Med. Phys. Fit. 2017, 57, 124-129. [CrossRef]

61. Judd, S.E.; Tangpricha, V. Vitamin D deficiency and risk for cardiovascular disease. Am. J. Med. Sci. 2009, 338, 40-44. [CrossRef]

62. Holick, M.F. The vitamin D deficiency pandemic: Approaches for diagnosis, treatment and prevention. Rev. Endocr. Metab. Disord. 2017, 18, 153-165. [CrossRef] [PubMed]

63. Liu, X.; Baylin, A.; Levy, P.D. Vitamin D deficiency and insufficiency among US adults: Prevalence, predictors and clinical implications. Br. J. Nutr. 2018, 119, 928-936. [CrossRef] [PubMed]

64. Orces, C.H. Association between leisure-time aerobic physical activity and vitamin D concentrations among US older adults: The NHANES 2007-2012. Aging Clin. Exp. Res. 2019, 31, 685-693. [CrossRef] [PubMed]

65. Ten Haaf, D.S.M.; Balvers, M.G.J.; Timmers, S.; Eijsvogels, T.M.H.; Hopman, M.T.E.; Klein Gunnewiek, J.M.T. Determinants of vitamin D status in physically active elderly in the Netherlands. Eur. J. Nutr. 2019, 58, 3121-3128. [CrossRef] [PubMed]

66. Kerschan-Schindl, K.; Föger-Samwald, U.; Pietschmann, P. Bone Turnover Markers. In Principles of Bone and Joint Research; Springer: Berlin/Heidelberg, Germany, 2017; pp. 55-66. [CrossRef]

67. Johansson, H.; Odén, A.; Kanis, J.A.; McCloskey, E.V.; Morris, H.A.; Cooper, C.; Vasikaran, S. A meta-analysis of reference markers of bone turnover for prediction of fracture. Calcif. Tissue Int. 2014, 94, 560-567. [CrossRef] [PubMed]

68. Mohr, M.; Helge, E.W.; Petersen, L.F.; Lindenskov, A.; Weihe, P.; Mortensen, J.; Jørgensen, N.R.; Krustrup, P. Effects of soccer vs swim training on bone formation in sedentary middle-aged women. Eur. J. Appl. Physiol. 2015, 115, 2671-2679. [CrossRef] [PubMed]

69. Jackman, S.R.; Scott, S.; Randers, M.B.; Orntoft, C.; Blackwell, J.; Zar, A.; Helge, E.W.; Mohr, M.; Krustrup, P. Musculoskeletal health profile for elite female footballers versus untrained young women before and after 16 weeks of football training. J. Sports Sci. 2013, 31, 1468-1474. [CrossRef]

70. Helge, E.W.; Andersen, T.R.; Schmidt, J.F.; Jørgensen, N.R.; Hornstrup, T.; Krustrup, P.; Bangsbo, J. Recreational football improves bone mineral density and bone turnover marker profile in elderly men. Scand. J. Med. Sci. Sports 2014, 24 (Suppl. 1), 98-104. [CrossRef] [PubMed]

71. Ferrucci, L.; Corsi, A.; Lauretani, F.; Bandinelli, S.; Bartali, B.; Taub, D.D.; Guralnik, J.M.; Longo, D.L. The origins of age-related proinflammatory state. Blood 2005, 105, 2294-2299. [CrossRef] [PubMed]

72. Fuller, K.; Murphy, C.; Kirstein, B.; Fox, S.W.; Chambers, T.J. TNFalpha potently activates osteoclasts, through a direct action independent of and strongly synergistic with RANKL. Endocrinology 2002, 143, 1108-1118. [CrossRef] [PubMed] 